\title{
Books and Resources Available for Review
}

Please contact Christine DeZelar-Tiedman (dezel002@umn.edu) if you are interested in reviewing one of the resources listed below.

\section{Books}

Arnar, Anna Sigrídur. The Book as Instrument: Stéphane Mallarmé, the Artist's Book, and the Transformation of Print Culture. Chicago: University of Chicago Press, 2011.

Cullingford, Alison. The Special Collections Handbook. London: Facet Publishing (dist. by Neal-Schuman), 2011.

Cuno, James. Museums Matter: in Praise of the Encyclopedic Museum. Chicago \& London: The University of Chicago Press, 2011.

Into Print: Limits and Legacies of the Enlightenment: Essays in Honor of Robert Darnton. Ed. by Charles Walton. University Park, Pa.: Pennsylvania State University Press, 2011

McGerr, Rosmarie Potz. A Lancastrian mirror for princes : the Yale Law School new statutes of England. Bloomington, Ind.: Indiana University Press, 2011

Staikos, Konstantinos. The History of the Library in Western Civilization: The Renaissance: From Petrarch to Michelangelo. New Castle, Delaware : Oak Knoll Press and HES \& DE GRAAF Publishers, 2012

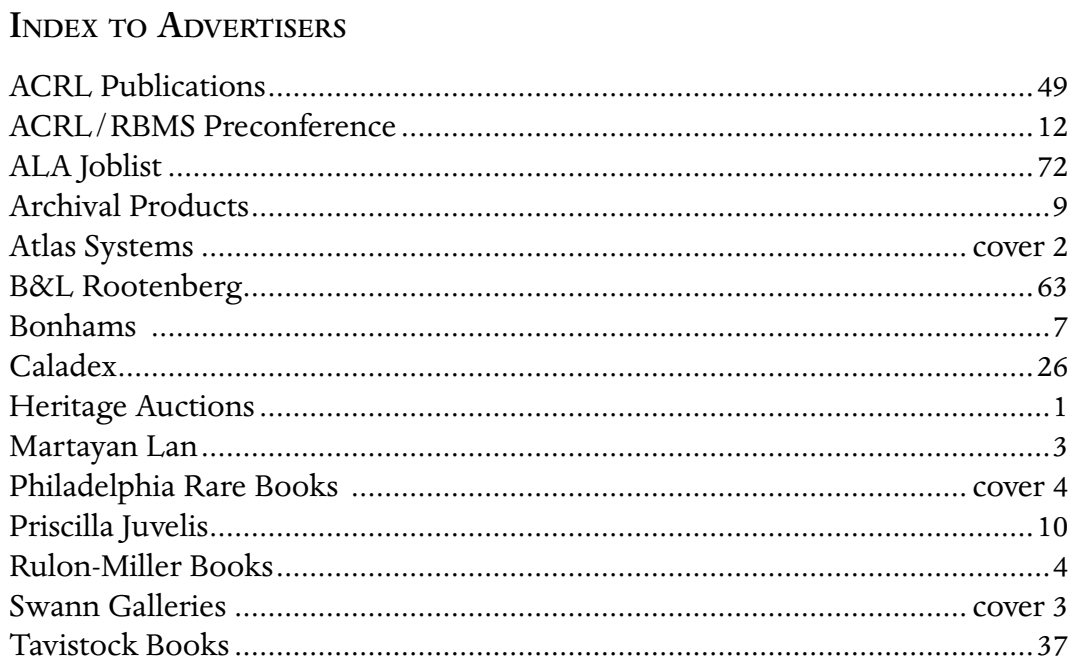

